\title{
DETERMINING QUORUM OF ATTENDANCE AND \\ DECISION MAKING IN THE GENERAL MEETING OF SHAREHOLDERS BASED ON COURT STIPULATION DUE TO THE NEGLECTFUL ABSENCE OF THE MAJORITY FOREIGN SHAREHOLDER IN A JOINT VENTURE COMPANY (A FOREIGN CAPITAL INVESTMENT ANALYSIS)
}

\author{
Ari Wahyudi Hertanto ${ }^{1}$
}

\begin{abstract}
The General Meeting of Shareholders (GMS) is one of the company's organs with the significant role of determining the business course and other issues related to corporate actions; as it is granted by law to the shareholders of the company. Any decision can be made in the GMS; such as determining the shareholders' unanimous concurrence on the proposed meeting agenda or even if the results of the meeting are actually contrary to such agenda caused by dissenting among themselves. However, the GMS can also pose certain obstacles in situations where one or more shareholders (that appear to be a majority shareholder) fail to act in good faith or have an internal dispute with other shareholder(s) in the company. The shareholder concerned can use such majority position to cause a dead-lock in the GMS, as a result of which the rest of the shareholder(s) are unable to make any decisions concerning the proposed GMS agenda. The aim of this article is to look at the effectiveness of Article 86 of the Indonesian Company Law for the purpose of overcoming the above described situation. The said Article 86 was formulated without considering the possibility of shareholders intentionally undertaking such unlawful measures. Moreover, the article is aimed at observing the concordance between the Indonesian Company Law and the Indonesian Procedural Law.
\end{abstract}

Keywords: General Meeting of Shareholders, GMS, Shareholder, Company, Joint Venture Company, Foreign Investment, Notary

\section{Introduction}

Business is something to be created in the context of business opportunities and development, with the primary objective of generating a certain amount of profits for the business actors involved, and thus keeping the wheels of economy rolling on a continuous basis. Business, as a form of economic activity, requires an organization to accommodate it. One of the generally known organizations is a limited liability company. In the process of the establishment of a limited liability company itself, there is an interesting

${ }^{1}$ Lecturer of Principles of Law, Faculty of Law, University of Indonesia. Obtained Bachelor of Law (S.H.) degree from University of Indonesia (1998), Master of Law (M.H.) degree from University of Indonesia (2005). The author can be reached at ari.didit@gmail.com 
characteristic which distinguishes between businesses conducted in western countries and eastern countries. While most western countries tend to prioritize the settlement of the legal aspects before actually starting to do business, eastern countries place greater emphasis on the business itself rather than the legal aspect of the same. To date, Indonesia is still quite heavily influenced by the characteristics of eastern countries.

Indonesia, as a country with abundant natural resources, has a special appeal to foreign investors. With its enormous natural riches still remaining unexplored, Indonesia is seen by foreign investors as a golden opportunity to develop their businesses. Not only that, with its population of over 200 million people, Indonesia is considered as an extraordinary and highly promising market, while on the other hand it is also considered that the cost of Indonesian labor force is relatively low compared to their respective country of origin. There are countries which possess financial surplus, sophisticated technology, and many other advantages; however, they lack abundant natural and human resources as well as low-cost labor force. It is in such context that opportunities for the realization of international business in the form of direct foreign investment arise.

Based on such perceptions and business opportunities, various forms of cooperation are initiated by business actors, one of them being what is generally known as joint venture. Experts have offered various opinions concerning the definition and essence of joint venture contracts, including the following: ${ }^{2}$ 1. According to Peter Mahmud, joint venture is "a contract between two companies to form a joint venture company."

2. $\quad$ Erman Rajagukguk et al define joint venture agreement as "a cooperation between the foreign owner of capital and national owner of capital based on an agreement (contractual)."

According to another definition, joint ventureisan association of two or more individuals or companies engaged in a solitary business enterprise for profit without actual partnership or incorporation; also called a joint adventure. $^{3}$

${ }^{2}$ http://prayitnobambang.blogspot.com/2011/11/bab-i-kontrak-joint-venture.html, retrieved on February 5, 2013.

${ }^{3}$ http://legal-dictionary.thefreedictionary.com/Joint+Venture, retrieved on February 5, 2013, whereas it is state further thata joint venture is a contractual business undertaking between two or more parties. It is similar to a business partnership, with one key difference: a partnership generally involves an ongoing, long-term business relationship, whereas a joint venture is based on a single business transaction. Individuals or companies choose to enter joint ventures in order to share strengths, minimize risks, and increase competitive advantages in the marketplace. Joint ventures can be distinct business units (a new business entity may be created for the joint venture) or collaborations between businesses. In a collaboration, for example, a high-technology firm may contract with a manufacturer to bring its idea for a product to market; the former provides the know-how, the latter the means. All joint ventures are initiated by the parties' entering a contract or an agreement that specifies their mutual responsibilities and goals. The contract is crucial for avoiding trouble later; the parties must be specific about the intent of their joint venture as well as aware of its limitations. All joint ventures also involve certain rights and duties. The parties have a mutual right to control the enterprise, a right to share in the profits, and a duty to share in any losses incurred. Each joint venturer has a fiduciary responsibility, owes a standard of care to the other members, and has the duty to act in Good Faith in matters that concern the common interest or the enterprise. A fiduciary responsibility is a duty to act for someone else's benefit while subordinating one's personal interests to those of the other person. A joint venture can terminate at a time specified in the contract, upon the accomplishment of its purpose, upon the death of an active member, or if a court decides that serious 
In Law No.25 of 2007 concerning Capital Investment, the provisions of Article 1 paragraph (3) set forth as follows:

"Penanaman modal asing adalah kegiatan menanam modal untuk melakukan usaha di wilayah Negara Republik Indonesia yang dilakukan oleh penanam modal asing, baik yang menggunakan modal asing sepenuhnya maupun yang berpatungan dengan penanam modal dalam negeri."

"Foreign capital investment is an activity for investing capital for the purpose of conducting business in the territory of the State of the Republic of Indonesia by foreign investors, either using entirely foreign capital or jointly with domestic investors" (Unofficial translation).

It means that the framework of joint venture is provided for under the law on capital investment. ${ }^{4}$

The implementation of joint venture agreement in the context of foreign capital investment activities is subsequently followed by the process for filing a foreign capital investment application with the Investment Coordinating Board (Badan Koordinasi Penanaman Modal, hereinafter briefly referred to as "BKPM") to seek approval for the investment concerned. Once an approval is issued for the foreign capital investment concerned, a limited liability company is established, also known as a joint venture company. Law Number 40 of 2007 concerning Limited Liability Company (hereinafter briefly referred to as "UUPT") in Article 7 paragraph (1) sets forth as follows:

"Perseroan didirikan oleh 2 (dua) orang atau lebih dengan akta notaris yang dibuat dalam bahasa Indonesia."

"A company shall be established by 2 (two) or more persons with a notary deed drawn up in the Indonesian language." (Unofficial translation)

In the Elucidation on the above mentioned Article 7 paragraph (1), it is stated as follows:

"Yang dimaksud dengan "orang" adalah orang perseorangan, baik warga negara Indonesia maupun asing atau badan hukum Indonesia atau asing. Ketentuan dalam ayat ini menegaskan prinsip yang berlaku berdasarkan undang-undang ini bahwa pada dasarnya sebagai badan hukum, Perseroan didirikan berdasarkan perjanjian, karena ini mempunyai lebih dari 1 (satu) orang pemegang saham."

disagreements between the members make its continuation impractical.

${ }^{4}$ Refer to Bambang Prayitno who wrote that,in the past, provisions concerned joint venture were set forth in the following laws and regulations:

- $\quad$ Article 23 of Law Number 1 Year 1967 concerning Foreign Capital Investment.

- Government Regulation Number 17 Year 1992 jo.Government Regulation Number 7 Year 1993 concerning the Ownership of Shares in a Foreign Capital Investment Company.

- Government Regulation Number 20 Year1994 concerning the Ownership of Shares in a Company established in the context of Foreign Capital Investment.

- Decree of the State Minister for the Mobilization of Investment Funds/Head of the Capital Investment Coordinating Board Number: 15/SK/1994 concerning the Implementing Provisions for the Ownership of Shares in a Company Established in the Context of Foreign Capital Investment.

${ }^{5}$ Refer also to the Elucidation on Article 8 paragraph (2) sub-paragraph (a) in which it is explained at the time of founding a company there is a need for clarity concerning the citizenship of its founders. Basically, Indonesian legal entities incorporated as a Company are established by Indonesian citizens or 
"Persons" is intended to mean individuals, either Indonesian or foreign citizens, as well as Indonesian or foreign legal entities. The provisions of this paragraph expressly confirm the prevailing principle based on this law that basically as a legal entity, a Company is established based on an agreement, therefore it has more than 1 (one) shareholders. (Unofficial translation)

The UUPT is non-discriminatory or in other words it provides for an equal opportunity to all "people" to establish a company in the form of a limited liability company in Indonesia, insofar as all provisions and requirements are fully complied with. Accordingly, the above mentioned joint venture agreement is materialized in the form an Indonesian legal entity, which is also a legal subject ${ }^{6}$ under civil law.

Pursuant to the above mentioned provisions of Article 7 paragraph (1), once the parties who enter into a joint venture agreement execute the limited liability company's deed of establishment, foreign investors must fully comply with and follow the various provisions of laws and regulations related to such joint venture company's activities, without any exception whatsoever.

Business does not always run smoothly and uninterruptedly, business activities often get disrupted even before they start. Such conditions can potentially occur due to various factors such as legal uncertainty, non-conducive

Indonesian legal entities. However, an opportunity is given to foreign citizens or foreign legal entities to establish an Indonesian legal entity in the form of a Company to the extent that the law concerning the business activities of such Company allow it or the founders of such Company are provided for under a specific law. In the event that the founders are foreign legal entities, the number and date of the incorporation of the legal entity of the founders concerned are treated as such equivalent documents, among other things the certificate of incorporation.

${ }^{6}$ The term corporate comes from the English language which is translated into Bahasa Indonesia as 'badan hukum' or 'legal entity', and it is a legal subject frequently referred to in literature as well as in everyday life. However, up to the present time, there is not a single clear definition of 'badan hukum' ('legal entity') under any existing laws or regulations. Therefore, for the definition of 'badan hukum' ('legal entity'), reference needs to be made to the following doctrines, among other things:

1. E.M. Meijers states that legal entities entail matters supporting rights and obligations.

2. Logemann states that legal entities are the personification, namely the manifestation or affirmation of rights and obligations.

3. Utrecht is of the view that legal entities are entities which are authorized under law to act as the supporter of rights, or in other words legal entities are non-living supporter of right.

4. Bothingk states that legal entities are only a non-human, juridical idea concerning identity capable of undertaking acts.

5. R. Subekti is of the opinion that a legal entity is essentially a body or association which can have rights and is capable of undertaking acts just as a human individual, and it can have assets of its own, can be sued and can file a suit before the court.

6. R. Rochmat Soemitro states that a legal entity is an entity which can have its own assets, as well as liabilities just as an individual person.

7. Wirjono Prodjodikoro defines legal entity as an entity which, just like a private individual, can also undertake acts under the law, which has rights, obligations and legal relations with other individuals or legal entities.

Based on the opinion of experts, R. Ali Rido concludes that there are 4 requirements/criteria elements in determining status as a legal entity, namely as follows:

1. There are separate assets;

2. It has specific objectives;

3. It has its own interests;

4. There is an orderly organization structure. 
political conditions, unstable defense and security, uncertain monetary situation, and a deadlock in internal disputes caused either by unfair practices, the absence of good faith of fellow shareholders, or similar situations. Such conditions can be experienced by any shareholder, regardless of the type of company, and it can equally affect joint venture companies. If a company experiences internal conflict, the stakeholders are certain to be directly impacted.

In Indonesia, joint venture agreements are normally signed by 2 (two) parties (bipartite), and even though it is very seldom the case, they are also sometimes signed by more than 2 (two) parties. A frequently occurring characteristic feature of joint venture is the foreign investor's dominant position $v i s-\grave{a}$-vis the domestic investor as manifested, among other things, in the proportion of at least 51\% (fifty-one percent) foreign and 49\% (forty-nine percent) domestic shareholding. Moreover, there are foreign investors whose shareholding exceeds 51\% (fifty-one percent), either in the form of explicit shareholding or non-explicit shareholding. ${ }^{7}$ In other words, foreign shareholders constitute a simple majority. Such position requires attention not only as a matter of strategy while business is running uninterruptedly, but it also calls for thinking about anticipatory measures in the future event of potential business disputes.

The question that arises is what happens if there is disagreement among the shareholders of a joint venture company. Such disagreement can eventually result in the foreign shareholder, who is notably the majority shareholder, simply abandoning the joint venture company concerned. That being the case, what should be done by the shareholder left behind in dealing with the various burdens and obligations arising from the transactions conducted as well as the legal acts previously undertaken by the limited liability company concerned.

In a situation like that, domestic shareholders will certainly find it extremely difficult to bear the burden posed by the various steps that need to be taken by the corporation towards the settlement of its internal as well as external affairs. One of the many existing measures that can be taken is using the option related to the attendance and decision making quorum in the General Meeting of Shareholders (hereinafter briefly referred to as "GSM"). The objective is to minimize losses and/or further difficulties encountered by domestic shareholders. The foreign shareholder's neglectful absence creates an imbalance in the company's routine operations. At the same time, prior to leaving their business and company in Indonesia, the foreign shareholder concerned had certainly engaged in transactional relations with various parties. Regardless of whether or not there is a dispute involved, an unresolved condition is left behind, namely the joint venture is not wound up, no claims are filed against the joint venture agreement or against a shareholder, and no legal remedies are taken by any of the shareholders towards their fellow shareholders. Consequently, the company faces an increasing level of uncertainty and ambiguity in dealing with the settlement of its obligations to third parties. Under such circumstances, the board of directors requires unequivo-

\footnotetext{
${ }^{7}$ It is possible to form joint ventures with the nominee mechanism or with additional agreements also normally referred to as underlying agreement granting additional powers to foreign shareholders concerning various matters. There is an element of confidentiality which the shareholders wish to maintain in order to ensure that business interests are not disrupted, although there may be several arrangements under such agreement which can be categorized as circumvention of the law.
} 
cal directions justified under the law in order to ensure that the steps taken by them in the management of the company are in no way contradictory to the applicable normative legal provisions.

\section{Normative Provisions concerning the Quorum of Attendance and De- cision Making in the GMS}

Before entering into an in-depth discussion concerning this matter, there is a need to understand the rules concerning the quorum of attendance and decision making in the GMS in normative terms. General provisions concerning the quorum of attendance and decision making in the GMS are set forth in Article 86, ${ }^{8}$ Article 88, ${ }^{9}$ and Article $89,{ }^{10}$ of the UUPT. In principle, the main distinctions among these three

${ }^{8}$ The provisions of Article 86 of the UUPT are as follows:

(1) A GMS may be held if it is attended or represented by more than $1 / 2$ (half) of the total shares with valid voting rights, unless a higher quorum is stipulated in this Law and/or the articles of association.

(2) In the event that the quorum as intended in paragraph (1) is not reached, notice for a second GMS may be sent.

(3) The notice for a second GMS must indicate that the first GMS was held and that the quorum was not reached.

(4) The second GMS as intended in paragraph (2) shall be valid and shall be entitled to adopt resolutions if attended by shareholders representing not less than $1 / 3$ (one third) of all shares with valid voting rights, unless the articles of association stipulate a greater total for quorum.

(5) In the event the quorum for the second GMS as intended in paragraph (4) is not reached, the Company may request the Head of the District Court whose jurisdiction covers the Company's domicile to determine the quorum for the third GMS upon the Company's request.

(6) The notice for a third GMS must indicate that the second GMS was convened but the quorum was not achieved, and the third GMS will be held with a quorum stipulated by the Head of the district court.

(7) The stipulation by the Head of the District Court concerning the quorum for a GMS as intended in paragraph (5) shall be final and shall have permanent legal force.

(8) The notice for the second and third GMS shall be sent by no later than 7 (seven) days prior to holding the second and third GMS.

(9) The second and third GMS shall be held no earlier than 10 (ten) days and by no later than 21 (twentyone) days after the preceding GMS. (Unofficial translation)

${ }^{9}$ The provisions of Article 88 of the UUPT are as follows:

(1) A GMS can be held to amend the articles of association if shareholders representing not less than $2 / 3$ (two thirds) of the total shares with valid voting rights attend or are represented in the GMS and the resolution shall be valid if approved by at least $2 / 3$ (two thirds) of the total votes cast, unless the articles of association stipulate a larger quorum of attendance and/or decision making in the GMS.

(2) In the event the quorum of attendance as intended in paragraph (1) is not achieved, a second GMS may be held.

(3) The second GMS as intended in paragraph (2) shall be valid and entitled to make a decision if not less than 3/5 (three fifths) of the total shares with valid voting rights are present or represented in the GMS and the resolution shall be valid if approved by not less than 2/3 (two thirds) of the total votes cast, unless the articles of association stipulate a larger quorum of attendance and/or decision making in the GMS.

(4) The provisions as intended in Article 86 paragraphs (5), (6), (7), (8) and (9) shall be applicable mutatis mutandis to a GMS as intended in paragraph (1).

(5) The provision as intended in paragraphs (1), (2), and (3) regarding the quorum of attendance and the provision on the requirements for adopting GMS resolutions shall also be applicable to a Publicly Listed Limited Liability Company unless otherwise stipulated in the laws and regulations governing capital markets.

\footnotetext{
10 The provisions of Article 89 of the UUPT are as follows:
} 
types of provisions concerning quorum can be briefly described as follows:

1. Article 86 provides for quorum and decision making in the GMS concerning agenda of general nature;

2. Article 88 provides for quorum and decision making in the GMS concerning agenda for the amendment of articles of association; and

3. Article 89 provides for quorum and decision making in the GMS concerning the following agenda:

a. Merger of the company;

b. Consolidation of the company;

c. Acquisition of the company;

d. Segregation of the company;

e. Filing for the company's bankruptcy;

f. Extending the company's term of establishment; and

g. Dissolution of the company.

Out of the above described three different approaches, this paper focuses on the quorum of attendance and decision making in the GMS concerning general agenda, as specifically provided for under Article 86 of UUPT. It is clearly stated that the agenda to be discussed in the GMS is an important object in determining whether or not the application of the provisions of Article 86 of the UUPT is relevant. Such general agenda of the GMS includes business transactions related to the company's business to be undertaken by the Board of Directors such as applying for a loan, pledging the company's assets as guarantee, sale of the company's assets and similar transactions. However, what happens if a deadlock or internal disagreement occurs among the shareholders of a company incorporated based on a joint venture agreement in the form of a foreign investment company? A situation in which there is no longer agreement for creating and maintaining harmony in business. Such situation is further exacerbated by the fact that the foreign investor loses interest and motivation for managing the company, simply abandoning it without a clear

(1) A GMS held to approve a Merger, Consolidation, Acquisition, or Segregation, a request for the Company to be declared bankrupt, have its duration of association extended, and the dissolution of the Company may be conducted if shareholders representing not less than $3 / 4$ (three fourths) of all shares with valid voting rights attend or are represented in the GMS, and the resolution shall be valid if approved by not less than 3/4 (three fourths) of the total votes cast, unless the articles of association stipulate a larger attendance quorum and/or requirements for adopting resolutions at the GMS.

(2) In the event the attendance quorum as stipulated in paragraph (1) is not achieved, a second GMS may be held.

(3) The second GMS as intended in paragraph (2) shall be valid and entitled to make resolutions if not less than $2 / 3$ (two thirds) of the total shares with valid voting rights attend or are represented in the GMS, and the resolution shall be valid if approved by not less than 3/4 (three fourths) of the total votes cast, unless the articles of association stipulate a larger attendance quorum and/or requirements for adopting resolutions at the GMS.

(4) The provisions as intended in Article 86 paragraphs (5), (6), (7), (8), and (9) shall be applicable mutatis mutandis to a GMS as intended in paragraph (1).

(5) The provisions as intended in paragraphs (1), (2), and (3) regarding the attendance quorum and/or the provisions regarding the requirements for adopting resolutions at the GMS shall also be applicable to a Publicly Listed Limited Liability Company unless stipulated otherwise in the laws and regulations governing capital markets. 
intention to settle the company's past affairs. The company is clearly bound to encounter various problems after it is abandoned by its foreign shareholders. Taking immediate steps for settlement becomes inevitable, particularly in the context of managing a major part or the entire assets of the company for the settlement of liabilities to all stakeholders. There are various ways provided for under the law, however, the law does provides for an alternative way through GMS decision making prior to taking strategic steps.

As for the quorum for decision making in the GMS concerning agenda on general matters, it is actually provided for both in the articles association as well as in Article 86 of the UUPT, as stated by M. Yahya Harahap, S.H. in his book with the title Hukum Perseroan Terbatas (Limited Liability Company Law), affirming that the quorum of attendance in the GMS to discuss agenda on general matters is as follows:

1. more than $1 / 2$ (one half) of the total shares with voting rights attend or are represented;

2. If such number is achieved, the GMS convened to discuss an agenda on general matters can be validly held.

As stated in the Elucidation on Article 86 paragraph (1), no deviations of such quorum of attendance are allowed. Accordingly, the company's articles of association:

1. may not provide for an attendance quorum which is less than $1 / 2$ (one half0 of the total shares with voting rights;

2. The company's articles of association may provide, however, for a quorum which is greater than the benchmark set forth in Article 86 paragraph (1). ${ }^{11}$

This is also affirmed in the last sentence of Article 86 paragraph (1), which contains the provision unless the law and/or the company's articles of associate provide for a greater quorum, implying that the company's articles of association may determine a quorum greater than that provided for under Article 86 paragraph (1). In providing for a greater quorum, the articles of association must comply with the following: ${ }^{12}$

1. If the quorum is not achieved, summons for a second GMS may be made.

The summons and holding of a second GMS, if the quorum of attendance in the first GMS is not achieved, are provided for in Article 86 paragraph (2). According to the elucidation on this article, in the event that the quorum for the GMS is not achieved, a second GMS can be summoned with the following procedure:

- the meeting must be opened and then adjourned;

- The minutes of the meeting should be drawn up stating that the first GMS could not be continued as the quorum had not been achieved.

a. Summons for the second GMS

${ }^{11}$ M. Yahya Harahap, Hukum Perseroan Terbatas (Limited Liability Company Law), third edition, PT. Sinar Grafika, Jakarta, 2011, p. 331-332.

${ }^{12}$ Ibid, M. Yahya Harahap, Hukum Perseroan Terbatas (Limited Liability Company Law), p.332. It needs to be understood that the UUPT provides for the minimum quorum, so that the company concerned can have more specific parameters for determining the quorum, which can be identical to or more than those provided for under the UUP, however, the reverse is not allowed. Under non-conducive circumstances, the law still gives an opportunity to minority shareholders through the same provisions to exercise their right in protecting the company's as well as their own individual interests. 
The summons for the second GMS should indicate, in addition to the matters provided for under Article 82 paragraph (2) (date, time, place and agenda, accompanied by information about the materials for discussion being available at the company's office), clarification on the following:

- the meeting must still be opened and then adjourned;

- Minutes of the meeting should be drawn up stating that the first GMS could not be continued as the quorum had not been achieved.

The summons for the second meeting can only be made after the above matters are complied with.

b. Quorum for the second GMS

In the event that the quorum for the first GMS is more than $1 / 2$ (one half) of the total number shares with voting rights attending or being represented, in the second GMS:

- The quorum shall be not less than $1 / 3$ (one third) of the total number of shares with voting rights attending or being represented; and

- The decisions shall be valid if approved by not less than $1 / 3$ (one third) of the total votes cast. ${ }^{13}$

c. Time frame for the second GMS summons

Summons for the second GMS shall be made by no later than 7 (seven) days prior to holding the second GMS.

d. Time for holding the second GMS

In order for the second GMS to be valid, it must be held:

- Within 10 (ten) days after the first GMS at the soonest; and

- By no later than 21 (twenty-one) days after the first GMS is held.

2. In the event that the quorum for the second GMS is not achieved, the company may request the Head of the District Court to stipulate the quorum for the third GMS.

Pursuant to Article 86 paragraph (5), if the quorum for the third GMS is not achieved:

- the company concerned may file a request with the Head of the District Court the jurisdiction of which includes the company's domicile;

- the essence of the request is asking the Head of the District Court to stipulate the quorum for the third GMS;

- No appeal, cassation or judicial review can be filed against such stipulation.

Yahya Harahap adds that in order to be able to take such measure, the guidance set out in the Elucidation on the above mentioned Article 86 paragraph (5) should be followed. Even though the quorum for the second GMS is not achieved, the GMS should are opened and then adjourned and the minutes of the meeting are drawn up stating that the second GMS could not be continued as the quorum had not been achieved.

${ }^{13}$ Yahya Harahap adds that this is based on Article 86 paragraph (4). However, the said Article grants the right to the company to determine a greater number as quorum in its articles association. 
a. Contents of the summons for the third GMS

According to Article 86 paragraph (6), in addition to the matters set forth in Article 83 paragraph (3), the summons for the third GMS must also indicate the following:

- the second GMS which was held;

- However, the quorum had not been achieved.

b. Time frame for the third GMS summons

Pursuant to Article 86 paragraph (8) concerning the time frame for the summons for the third GMS, such summons must be made by no later than 7 (seven) days prior to holding the third GMS. This provisions on the time frame is different from the summons for the first GMS, namely 14 (fourteen) days prior to the date of holding the GMS.

c. Time for holding of the third GMS

The third GMS must be implemented within a limited time frame, in compliance with the provisions of Article 86 paragraph (9), setting forth as follows:

- within 10 (ten) days after the second GMS is held at the soonest; and

- By no later than 21 (twenty-one) days after the second GMS is held.

d. The decision making procedure in a GMS concerning agenda on general matters

The decision making process in a GMS concerning agenda on general matters is provided for under Article 87 of UUPT:

1) As a basic principle, resolutions of the GMS are adopted based on deliberation to reach consensus. In the Elucidation on Article 87 paragraph (1) it is explained that deliberation to reach consensus is intended to mean the results of agreement reached approved by the shareholders attending or represented in the GMS concerned.

a) It is conducted through voting. Voting is conducted only if no agreement is reached based on deliberation for consensus. That being the case:decisions are made by voting;

b) A decision is valid if approved by more than $1 / 2$ (two half) of the total votes cast, unless a greater number is set forth by law and/or in the articles of association. ${ }^{14}$

\section{III.Implementation of Quorum of Attendance and Decision Making in GMS In the Event that the Company Is Abandoned by Its Foreign Shareholder}

${ }^{14}$ Yahya Harahap adds that pursuant to the Elucidation on Article 87 paragraph (2), being approved by more than $1 / 2$ (one half) of the total shares is intended to mean the following:

1. The proposal in the meeting agenda must be approved by more than $1 / 2$ (one half) of the total votes cast, generally referred to as simple majority or $50 \%$ (fifty percent) +1 (one).

2. If there are 3 (three) proposals or candidates and none of those achieve $1 / 2$ (one half) of the total share votes, voting concerning 2 (two) proposals or candidates with the greatest number of votes must be repeated, so that one of the proposals or candidates obtains more than $1 / 2$ (one half) of the total votes cast. 
Although it does not happen very often, reality in practice has shown that there have been instances of foreign shareholders bound by a joint venture agreement leaving Indonesia, without taking responsibility for the various obligations that they ought to resolve. Consequently, Indonesian shareholders are faced with the unfortunate situation of appearing to be solely responsible for all of the company's obligations. Following are some of the company's obligations to stakeholders, among other things:

1. accounts payable due to vendors;

2. credit agreements, both in the form of banking and other financial institution facilities which must be settled;

3. tax or royalty payable (if any);

4. obligation to complete a project or work, related to the company's business activities which must be settled by the company concerned;

5 . the obligation to pay salary to employees;

6. the obligation to settle payments related to office operations;

7. etc.

A debt is a debt, and as such it must be settled. Determining the steps that the company must take when faced with such a delicate situation is not an easy task. The underlying idea is that all issues arising as a consequence of business activities are created as a result of transactions conducted in the context of commercial arrangements, wherefore the company needs to take concrete steps towards repositioning or even bringing to an end the company's obligations. In fact, there are many options for the settlement of a company's obligations; however, the challenge is how to find the most accurate and appropriate way to resolve the problem, ${ }^{15}$ with commercial and legal impacts which do not cause any further difficulties and losses to the company concerned. Briefly, what are the concrete measures to overcome problems arising from several credit facilities which have become due and payable or even overdue, with potential implications on the company's default? How to avoid a situation where the bank files or brings such case to the court? The company concerned needs to take immediate anticipatory steps. One way to go is to submit to the provisions of Article 86 of the UUPT, however, several issues need to be noted if this avenue of settlement is taken, namely as follows:

${ }^{15}$ Alternative settlement can be made by (1) selling the company's shares to a third party, however, the absence of the foreign shareholder in its capacity as the owner selling its shares to a third party is an obstacle which must be considered, particularly in view of the validity of a sale and purchase. The specific business characteristics of a joint venture company must be considered when determining a new partner as potential replacement of the former foreign shareholder. Things become difficult when such new candidate sets rather high requirements, resulting in absolute domination as opposed to the proportionality in the position of the respective parties. (2)The option to file for bankruptcy with the Court is also an inappropriate measure, as the negative impacts thereof are bound to affect directly the domestic shareholders, as well as the board of directors and board commissioners of the company concerned, as they are going to be registered as organs which have been part of, or which have been involved in the management of a bankrupt company. Although it may not be the case altogether, the juridical consequences still need to be considered. (3) Dissolving the company is another measure that may be taken. This maneuver is conducted in an effort in anticipation of the possibility of a bankruptcy petition being filed with the Court by one of the stakeholders. As we all know, the process for the dissolution of the company in such a situation follows the procedure set forth in the provisions of Article 89 of the UUPT. 


\section{A.The provisions of Article 86 of the UUPT are not entirely effective}

Why is it considered that the provisions of Article 86 of the UUPT are not entirely effective in resolving this issue? One of the underlying reasons is that Article 86 of the UUPT was not entirely designed to deal with conflicts whereby one of the shareholders is absent or has even run away. That is to say, this article is in fact more appropriately aimed at a GMS in which all shareholders attend and are represented, whereas the participants attending fail to reach consensus in formulating the resolution of the meeting due to a deadlock in the decision making process. To put it simply, the drafters of this law formulated this article for implementation under normal and regular circumstances, or for other reasons such as the shareholders' unclear address. However, Article 86 of the UUPT fails to take into account the possibility of a majority (or controlling) shareholder being absent from the GMS, while in fact this factor can actually cause the non-achievement of quorum, even though the shareholder concerned is duly summoned to attend the GMS.

Furthermore, good faith is a key element in dispute settlement. In the sample case given in this paper, the quorum of attendance and decision making in the GMS is obviously not going to be achieved. At the same time, the provisions of Article 86 of the UUPT are based on the principle as stated in the Elucidation on Article 87 paragraph (1) of the UUPT, namely through the pattern of deliberation for consensus formulating the results of the agreement approved by the shareholders attending or represented in the GMS. According to the adagium, good faith does not need to be proven; in fact, it is the absence of good faith that requires substantiation. However, sometimes the factor of neglectful absence or non-representation of a shareholder in the GMS may be an element of deliberateness. In other words, an internal disagreement may already have occurred even before holding the GMS. If there are indeed prior indications of disharmony in doing business or in communications, should good faith be maintained, or just the contrary? Furthermore, it may be difficult to state directly or prove the motives behind the absence or non-representation of a shareholder in the GMS, namely whether it is intentional or whether it is caused by another genuine and acceptable reason.

Article 87 of the UUPT provides for an opportunity to conduct voting. What happens, however, if the company has only 2 (two) shareholders. If that is the case, voting is obviously not effective, and it is not a feasible option. Accordingly, the way to go is for the shareholders to file a request with the Court, basically asking the Court to issue a stipulation to reduce the quorum for the meeting vis-à-vis the quorum provided for in the company's articles of association. The purpose of doing so is to enable the GMS to adopt resolutions even though it is not attended by other shareholders or their representatives. There are certain challenges in the process of filing such request, which will discussed in the subsequent chapters of this article.

\section{B. There is a lack of understanding among companies that the time frame for holding the first up to the third GMS as provided for under Ar- ticle 86 paragraphs (8) and (9) of the UUPT is absolute}

There are explicit provisions to that effect in Article 86 paragraphs (8) 
and (9) of the UUPT, providing as follows:

“(8) Pemanggilan RUPS kedua dan ketiga dilakukan dalam jangka waktu paling lambat 7 (tujuh) hari sebelum RUPS kedua atau ketiga dilangsungkan.

(9) RUPS kedua dan ketiga dilangsungkan dalam jangka waktu paling cepat 10 (sepuluh) hari dan paling lambat 21 (dua puluh satu) hari setelah RUPS yang mendahuluinya dilangsungkan."

"(8)The notice for the second and third GMS shall be sent by no later than 7 (seven) days prior to holding the second and third GMS.

(9)The second and third GMS shall be held no earlier than 10 (ten) days and by no later than 21 (twenty-one) days after the preceding GMS." (Unofficial translation)

The time frame related provisions set forth in Article 86 paragraphs (8) and (9) of the UUPT as quoted above are an absolute requirement for shareholders in filing a request with the Court asking it to stipulate the quorum of attendance and decision making in the GMS. It means that holding the first GMS up to the summons for the third GMS must be conducted in an uninterrupted time interval as provided for in the above mentioned article.

Not all companies incorporated as a limited liability company have an internal legal division, and neither do they all use the services of legal consultants or even notaries. As a consequence of the absence of such instruments, a potential lack of understanding of the UUPT articles may occur. That may be the reason why companies experiencing a deadlock related to the quorum of attendance and decision making in the GMS state it in the forum concerned determining the time frame of 2 (two) months and subsequently hold the second GMS within such time frame. In the second GMS, with the quorum of attendance and decision making still not being achieved, the attending shareholders propose to convene the third GMS within the same time frame as the one determined in the summons for the preceding second meeting, namely within the next 2 (two) months.

With reference to the above described case, the summons for the second meeting determining the subsequent meeting as the second GMS within the time frame of 2 (two) months cannot be considered as the holding of second GMS if we fully adhere to the provisions of Article 86 of the UUPT. In other words, the above mentioned meeting postulated as the second meeting will continue to be considered as the first meeting and it cannot be used as a basis to file for the Court stipulation process. If it is considered that the second GMS is identical to the first GMS, it is obvious that (summons for) the third GMS cannot possibly occur.

\section{C.Multi-layered Joint Venture Agreement}

In the foreign investment application form it is required that in the event of a company being established in the context of joint venture, a copy of the joint venture agreement concerned must be attached as one of the documents which must be submitted to BKPM. In principle, joint venture agreements articulate the agreements of the parties thereto concerning the framework of cooperation serving as a basis for establishing a company in Indonesia. The matters and substance of such joint venture are subsequently dealt with as 
reflected in the articles of association of the limited liability company being established.

Investors may occasionally have other interests which cannot be simply formulated in the joint venture agreement concerned. Why is that the case? It is because the joint venture agreement is being submitted to BKPM officials, while foreign investors may wish to limit access to certain information to internal related parties only. Accordingly, in addition to the joint venture agreement, there may be sets of other agreements such as, among other things, shareholders agreement, debt and receivables agreement, irrevocable power of attorney and similar agreements. These supporting agreements are usually strictly confidential in nature. They may not be disclosed even to the directors or board of commissioners who are not among the joint venture company's shareholders.

In situations like this, domestic shareholders are normally positioned only as nominees, or they appear as minority shareholders, while in fact they hold such shares on behalf of the foreign investors concerned. However, in some instances, the above mentioned set of agreements is not formulated in the context of nominee arrangements, but rather the instruments are prepared in the context of circumventing the law, as foreign investors may find themselves faced by certain challenges in protecting their business interests in Indonesia due to, for example, the presence of an informal management within the formal management, the determination of quorum of attendance and decision making in the GMS regarding certain issues in contradiction to the provisions of the UUPT, and the like.

That being the case, domestic shareholders would find themselves in a difficult position. GMS are held merely for formality's sake, whereby it is the ultimate shareholder of the company who enjoys all the benefits derived from the structure of such stealth agreements. Thus, it may well be the case that despite the GMS having been held, the ultimate shareholder states its disagreement, whereby it is considered that the GMS is invalid and the wish of the ultimate shareholder prevails, even though it may be substantively unlawful. Accordingly, the effective implementation of Article 86 of the UUPT in this case is put to the test yet again.

\section{D.The directors and the board of commissioners are reluctant to make decisions}

On the one hand, shareholders have interest in the company owned by them, while on the other hand directors have the authority to manage the company. Viewed from the foreign investors' point of view, the directors and commissioners of a joint venture company are not necessarily the shareholders of such company. This is due to the possibility of the foreign shareholders' being a multinational corporation, while from the local shareholders' viewpoint such possibility does not exist. The imbalanced position of the parties in a joint agreement is a factor which actually affects the performance of directors or commissioners. The option for such directors and commissioners is either to remain in their respective positions, namely with the conditions unchanged, or to leave the company concerned. This option comes up because occasionally there are situations whereby the shareholders' wishes exceed the wishes of the limited liability company concerned. The shareholders are using the limited liability concerned merely as an instrument/vehicle for the 
achievement of their own interests while disregarding the various interests prescribed by the applicable laws and regulations. This may occur due to a discrepancy between the shareholders' and directors' interest respectively in view of the provisions of the UUPT, and even due to a discrepancy between the shareholders' and the company's interests.

At the same time, in implementing their functions, the directors have certain authorities to conduct the transactions of the limited liability concerned. However, conditions occurring and taking place among shareholders are beyond the control of directors. What is the reason for that? In conducting the company's activities, the old paradigm still prevails sometimes, namely that the centrum of a company is the GMS through its shareholders. Meanwhile, the directors and board of commissioners are considered to be mere instruments used to achieve the shareholders' business objectives. However, in view of the UUPT, such arrangements are no longer relevant as each of the organs have their respective functions.

Furthermore, the directors of the company run the company's business activities based on the principle known as the fiduciary duties of directors. The directors are required at all times to implement their fiduciary functions consistently, in order for them to be released from liability if circumstances for accusation of causing the company to suffer losses occur. This is in compliance with the provisions of Article 97 paragraph (4). The qualifications as intended above are as follows:

"Anggota Direksi tidak dapat dipertanggungjawabkan atas kerugian sebagaimana dimaksud pada ayat (3) apabila dapat membuktikan:

a. kerugian tersebut bukan karena kesalahan atau kelalaiannya;

b. telah melakukan pengurusan dengan itikad baik dan kehati-hatian untuk kepentingan dan sesuai dengan maksud dan tujuan Perseroan;

c. tidak mempunyai benturan kepentingan baik langsung maupun tidak langsung atas tindakan pengurusan yang mengakibatkan kerugian; dan

d. telah mengambil tindakan untuk mencegah timbul atau berlanjutnya kerugian tersebut."

"Members of the BOD cannot be held liable for losses as intended in paragraph (3) if they are able to prove that:

a. such losses were not caused by their mistake or negligence;

b. they have managed in good faith and prudently for the interest and in accordance with the purposes and objectives of the Company;

c. they do not have a conflict of interest either directly or indirectly in their management acts causing the losses; and

d. they have taken action to prevent the said losses from occurring and continuing." (Unofficial translation)

The relevance between the provisions of the above quoted Article and the application of the quorum of attendance and decision making in the GMS is that it is the directors who are in charge of conducting the meeting and preparing invitations to the GMS. Even though invitations are initiated by the shareholders, the decision making process in the GMS has a great impact on the company's performance and it is indirectly related to the efficiency of the 
directors' performance. In the particular case which is also the title of this article, it is the directors who are handling settlement with stakeholders using the company's assets. In doing so, the directors are most likely to take an extremely cautious attitude. The reason for taking such attitude is to avoid being potentially put in the position of a defendant in the future under the accusation of having used company assets belonging to the majority shareholder without the latter's prior consent. The foreign shareholders concerned may no longer be in Indonesia, however, the opportunity for them to seek remedies in order to uphold their interests remains open.

According to the UUPT, commissioners are also in the position of having fiduciary functions. Pursuant to the provisions of Article 115 of the UUPT, commissioners, as overseers of the limited liability company, also have fiduciary duties. If they intentionally or negligently commit a mistake in implementing such fiduciary duties, in the sense that they fail to implement their functions in good faith and in a responsible manner for the interest of the limited liability company concerned, commissioners can be held personally liable. In other words, any such non-conducive circumstances must be promptly followed up by the commissioners with the directors, in order to ensure that uncertainty is quickly overcome.

Exceptions can be made to the extent that the Commissioners have acted consistently in implementing their fiduciary functions in view of a deviation which has occurred, in compliance with the provisions of Article 114 paragraph (5). The qualifications as intended above are as follows:

"Anggota Dewan Komisaris tidak dapat dipertanggungjawabkan atas kerugian sebagaimana dimaksud pada ayat (3) apabila dapat membuktikan:

a. telah melakukan pengawasan dengan itikad baik dan kehati-hatian untuk kepentingan Perseroan dan sesuai dengan maksud dan tujuan Perseroan;

b. tidak mempunyai kepentingan pribadi baik langsung maupun tidak langsung atas tindakan pengurusan Direksi yang mengakibatkan kerugian; dan

c. telah memberikan nasihat kepada Direksi untuk mencegah timbul atau berlanjutnya kerugian tersebut."

"Members of the Board of Commissioners may not be held liable for the losses as intended in paragraph (3) if they are able to prove that:

a. they have conducted supervision in good faith and prudently for the interest of the Company and in accordance with the purposes and objectives of the Company;

b. they have no personal interest either directly or indirectly in the management acts of the Board of Directors that have caused losses; and

c. they have offered advice to the Board of Directors to prevent the losses from occurring or continuing." (Unofficial translation)

In implementing their respective fiduciary functions, the directors as well as the board of commissioners are strongly advised to duly observe 4 important aspects of good corporate governance, namely as follows ${ }^{16}$ :

${ }^{16}$ Low CheeKeong, Introduction the Corporate Governance Debate, Corporate Governance an Asia Pacific Critique, Sweet \& Maxwell Asia a Thompson Company, p.41. 
1. accountability, along with the variables for the assessment of the level of accountability, including the following:

a. independence and non-executive nature of board members;

$b$. presence of more than half non-executive board members;

c. presence of foreign nationals on the board;

$d$. occurrence of regular full-board meeting (once a quarter);

e. opportunity for the members to "exercise effective scrutiny"; and

$f$. presence of audit committee.

2. Transparency, including the following:

a. adoption of accurate accounting methods;

$b$. full and prompt disclosure of information relating to the company;

c. timely disclosure of information;

$d$. disclosure of conflicts of interest of the directors or majority shareholders; and

e. Adequate advance notice of meetings and voting so shareholders may prepare.

3. Minority investor protection measures, under this item, in principle the author places greater emphasis on transparency and accountability which are still considered to be inadequate and are not supported by concrete measures for the protection of minority shareholders who frequently receive unfair treatment.

4. The non-compliance of limited liability companies is related to enforced regulations, being the key element which determines success or failure in the implementation of good corporate governance principles in a country. In other words, every country which has ratified good corporate governance principles should be aware of its commitment to apply comprehensive policies as a mandatory guarantee for the implementation of such principles. Another important factor is related to the binding force of regulatory instruments (law) as well as the imposition of effective sanctions against parties who do not comply with such principles.

The starting point for all of the foregoing is that all authority related matters in a company are integrated with the implementation of the ultra vires doctrine. At the same time, the authorities of a limited liability company are derived from the following sources: ${ }^{17}$

1. Laws and regulations.

2. The company's articles of association.

3. Practices supervised by the relevant government departments and decisions made by judicial bodies.

In fact, it is evident from the foregoing that the directors and board of commissioners must proceed with the settlement of the company's obligations towards its stakeholders. The implementation of the settlement process is part of the implementation of their fiduciary functions, in which they are continuously required to observe good governance and intra vires principles.

${ }^{17}$ Op.Cit, p.122-123. 
Even though the directors and the board of commissioners exercise due diligence in implementing their functions in accordance with the applicable regulations, there is no guarantee that there will be no claims by foreign shareholders holding an interest in the assets of the company concerned. Another aspect that needs to be noted is a situation when the joint venture agreement is made as described in part 4 hereinabove, whereby the directors and the board of commissioners are completely unaware of certain agreements made without them being informed about the same.

\section{E. The time frame requirement for filing for the Court Stipulation process is not properly observed}

The summons for the third GMS which are limited to a maximum of 21 (twenty-one) days is an inadequate time frame for the process of filing a request for court stipulation..$^{18}$ In general, the phases involved in the process of filing for court stipulation are as follows:

a. The request is filed and registered by submitting the request dossier along with the special power of attorney. This process takes about 1 (one) week.

b. The legal division submits the dossier to the Head of the District Court for the appointment of a judge. It can be either a panel of judges or an individual judge, appointed based on a stipulation issued by the Head of the District Court. This process takes about 1 (one) week.

c. After a formal appointment is issued, the judge concerned determines the day of the hearing. This process takes about 1 (one) week.

d. Official and appropriate summons is served on the petitioner to appear (relaas) in the District Court related to the request for stipulation. This process takes about 1 (one) week if the summons is served within the jurisdiction of the District Court concerned. The time frame will be totally different if delegation is involved due to different territories, which will normally take more than 1 (one) week. In addition to that, it needs to be noted that if the official and proper summons (relaas) is not duly responded to, repeated summons will be served not exceeding 3 (three) additional summons as from the first summons. If the 3 (three) officially and properly made summons are not responded to by the party being summoned, and

${ }^{18}$ Refer to M. Yahya Harahap, in his book Hukum Acara Perdata concerning Gugatan, Persidangan, Penyitaan, Pembuktian dan Putusan Pengadilan(Civil Procedural Law about Claim, Hearing, Seizure, Substantiation and Court Decision), second edition, PT. Sinar Grafika, Jakarta, June 2005, on page 29 it is stated that the request or voluntary claim is a matter of civil law which is filed in the form of a request signed by the requesting party or its attorney-in-fact addressed to the Head of the District Court concerned. The characteristic features of a voluntary claim are as follows:

1. The subject matter of the claim being filed is for the benefit of one party only.

a. It is purely for the resolution of a claim concerning a civil issue requiring legal certainty, for instance requesting the court's permission to undertake a certain act;

b. Accordingly, in principle, the claim filed by the requesting party does not concern the rights of another party.

2. The issue being filed for adjustment with the District Court is in principle without disputes or differences with another party. Based on such criteria, it is not acceptable to file claims for the settlement of disputes concerning rights or ownership or payment by another party or a third party.

3. There is no other party or third party included in the claim as respondent; rather, it is ex parte in nature. It purely and absolutely involves only one party, so it is ex-parte in nature. The request is filed on behalf of one party, involving only one party to a legal matter in the case. 
in the absence of a probability that the party concerned will appear in the hearing, the judge starts the hearing process to examine the request. The initial time frame of only 1 (one) week is obviously going to change to become about 3 (three) to 4 (four) weeks.

e. In the first hearing, the parties related to the examination are asked questions concerning their identities and capacities, as well as about the purpose of filing the request for court stipulation. Generally, the hearing is adjourned for 1 (one) week in order to prepare witnesses and written evidence.

f. In the hearing in which witnesses and evidence are examined the judge is normally able to determine whether the request can be accepted or whether it is to be rejected.

g. The judge issues a decision on the stipulation.

$\mathrm{h}$. The decision concerning the stipulation is submitted to the petitioner only after the petitioner has the stipulation published in a daily newspaper.

Based on the foregoing, it is clear that in reality, the chronology of the process of applying for a stipulation exceeds 21 (twenty-one) days. It means that the provision concerning the time frame for holding the third GMS as intended in Article 86 paragraph (9) of the UUPT, essentially setting forth that the third GMS is to be held based on the decision concerning the court stipulation, is not really effective.

The time frame related constraints do not stop there. If it turns out that one of the shareholders is a foreigner who is no longer in Indonesia, the process for official and proper summons (relaas) is automatically bound to take even longer. Why so? In such case, the court has to send the summons by way of delegation. Delegation is made to the embassy of the above mentioned foreign shareholder's country of origin. The time frame for delegation within the state territory of the Republic of Indonesia is obviously not the same as opposed to the time frame involved if the summons has to be sent overseas by registered mail. It is implied in this description of the delivery process that the following the issuance of the summons by the District Court, it is sent to the embassy, which then forwards it through the relevant institution in the country represented by it, and it is subsequently sent on to the foreign shareholder concerned. Following such process, there are two probabilities, namely there is a direct or indirect response, through the embassy concerned; or there is no response whatsoever. If there are obstacles, the summons will be sent 3 (three) times, which is estimated to take about 3 (three) months. As a matter of additional information it needs to be noted that the District Court is not going to send the summons directly to the foreign shareholder concerned at such shareholder's domicile in his/her country of origin. Rather than that, the standard dispatch procedure is going through the respective embassy in Indonesia.

\section{F. The notary is bound to refrain from taking any steps outside the scope of the provisions of law}

The notary is bound to take the stance that there is not much that can be done if the time frame is exceeded while waiting for a decision to be made 
concerning the Court stipulation on GMS attendance and decision making quorum. If the time frame as intended in Article 86 paragraph (9) is exceeded, the third GMS cannot be held, either at that particular time, or at any point in time in the future for that matter. Acting in his/her capacity as a state official, the notary concerned is not in a position to seek dispensation from the District Court related to time frame, because the provisions of Article 86 paragraphs (8) and (9) provide for a different time frame as opposed to the time frame for the decision making process concerning stipulation; thus the notary cannot require the Court to accelerate the process of issuing a decision concerning stipulation. It is quite clear that in implementing the provisions of the UUPT, the notary is subject to laws and regulations related to the duties and the office of a notary, while on the other hand, the District Court, too, is bound by other laws and regulations related to judicial power, particularly related to the process of Court proceedings.

\section{Alternative Dispute Resolution}

In this section, the alternative means of dealing with such situations will be discussed, namely as follows:

\section{A.Holding the GMS}

The invitation for the first GMS is sent in order to ensure that the meeting can be held on the determined date. In this case, the minutes of the first GMS must indicate the fact about the non-achievement of the GMS attendance and decision making quorum in compliance with the provisions of the articles of association and the UUPT. In other words, the first GMS cannot adopt resolutions of the GMS. As soon as the first GMS is adjourned, the directors are immediately instructed to prepare an invitation for the second GMS in compliance with the time frame provided for in Article 86 paragraphs (8) and (9).

Then the second GMS is held, however, as was the case in the first GMS, the quorum for GMS attendance and decision making is not achieved. The minutes of the second GMS must take note of the fact that, yet again, the second GMS cannot adopt resolutions of the GMS due to the non-achievement of the GMS attendance and decision making quorum. As soon as the second GMS is adjourned, the directors are immediately instructed to prepare the filing of request with the District Court to issue a stipulation for determining the quorum for the third GMS.

With the assumption that the court's decision concerning such stipulation cannot be issued within the time frame of 21 (twenty-one) days after holding the second GMS, the third GMS continues to be held within the time frame as provided for in Article 68 paragraph (9). In its implementation, the agenda of the third GMS must remain consistent by indicating the agenda previously mentioned in the invitations for the first GMS and the second GMS respectively. In the third GMS, it is added in one of the items of the agenda that the decisions made in the third GMS will be subject to and will comply with the stipulation decision issued by the District Court in view of the request for the determination of quorum for the third GMS. 
After the Court's decision concerning the stipulation is issued ${ }^{19}$, the shareholders will immediately prepare an invitation for GMS, for the purpose of holding a GMS based on the Court's stipulation. The said GMS is a confirmation of the third GMS held by the company, therefore the decisions made by the GMS will highly depend on whether the request for stipulating the quorum is accepted or rejected. If it is accepted, this confirmation GMS basically affirms the implementation of the agenda of the first, second and third GMS respectively.

On the other hand, if the request is rejected, the confirmation GMS basically affirms that the agenda of the first, second and third GMS cannot be implemented. If the request for stipulation is rejected, there is a high probability that no stipulation GMS will ever be held. However, in order to maintain an orderly administration of management, it must still be done.

\section{B. Time frame for sending documents overseas}

Special efforts need to be made for dealing with the issue of time frame for sending documents overseas based on the standard procedure by delivery through the diplomatic mission in Indonesia, and then forwarded to the foreign shareholder concerned in the country of origin. Such process starts with informing the Head of the District Court and the judge in charge of conducting the stipulation hearing to send the official and appropriate summons (relaas) to the domicile of the joint venture company addressed to the foreign shareholder concerned. The company is obligated to issue a receipt acknowledging the receipt of such official and appropriate summons (relaas).

The next step that the company must take is to convey the said official and appropriate summons (relaas) through the various means of communication available, either by sending the original dossier by registered mail, by telephone, facsimile, electronic mail or even video conference. Evidence

${ }^{19}$ Refer to M. Yahya Harahap, Ibid, p. 31. One of the examples for obtaining a better understanding of the basis for voluntary jurisdiction is quoted in the Stipulation of the Supreme Court No. 5 Pen/ Sep/1975 (June 1973) in the case of Forest Products Corp. Ltd. The Central Jakarta District Court made a voluntary decision in request No.274/1972 as follows:

The decision was rendered on June 27, 1972;

The contents of the decision was as follows:

1. Stating that the GMS was valid;

2. Stating that the agreement made was not binding on Forest Production Corp Ltd.

At the request of the party which felt it was negatively affected by the Central Jakarta District Court's above mentioned voluntary decision, the Supreme Court issued stipulation No.5 Pen/Sep/1975 containing the following considerations and affirmations, among other things:

1. Declaratory statement (dekralatoir) on the validity of the GMS and the organizational structure of the management, as well as the non-binding nature of the agreement through the voluntary (voluntair) claim, being contradictory to the processual principle;

2. From the processual point of view, the voluntary (voluntair) stipulation issued by the District Court in this case must be based on a contentiosa claim;

3. The voluntary (voluntair) jurisdiction is valid only if it is determined by law.

Quoting the same source, Prof. Sudargo Gautma is of the view, among other things, that in the event of voluntary settlement of a case which has elements of dispute:

1. Where an ex-parte process has already taken place;

2. It means that the dispute settlement is in violation of the due process (goede process orde), and at the same time it violate the principle of audi alteram partem (the counter party's right to defense and the right to defend its interest);

3. While the party against which the voluntair request is filed in this case should be heard as a party. 
of such delivery should be submitted to the handling judge, serving as proof that the company has made the necessary endeavors to send such documents hence the official and appropriate summons (relaas) was duly served.

The purpose of the above described procedure is to avoid the time-consuming bureaucratic process involved if the dispatch is conducted through the diplomatic mission concerned. At the same time, from the normative point of view, such measure is not contradictory to the applicable laws and regulations, as the foreign shareholder concerned is still registered as having domicile at the address of the joint venture company.

\section{The drawing up of a notary deposit deed (akte van depot) on the GMS in which no resolution is adopted}

As described in the above mentioned cases, the first and second GMS, and in fact even the third GMS do not produce a resolution. However, in the minutes of the meeting it is noted that the third GMS shall be subject to and shall comply with the decision concerning the court stipulation to be issued by the District Court in view of the request for determining the quorum of the third GMS. In this case, the notary will not draw up a Deed on the Statement of the Resolution of the Meeting.

The notary's task is to draw up the Deed on the Minutes of the GMS if the notary attends the meeting, or to draw up the Deed on the Statement of the Resolution of the Meeting if the notary does not attend the GMS but the Board of Directors and/or their appointed proxy are instructed at the end of the GMS to make arrangements for the minutes of such GMS to be stated in the form of a notary deed. Either of the above described deeds can be drawn up after a resolution is adopted in the GMS concerned.

The above mentioned minutes of the first, second and third GMS belong to the category of privately drawn up deeds, as set forth in the provisions of Article 1867 as follows:

"Pembuktian dengan tulisan dilakukan dengan tulisan-tulisan otentik maupun dengan tulisan-tulisan di bawah tangan."

"Written evidence occurs in authentic or privately drawn up documentation." (Unofficial translation)

Written evidence consists of deeds and other types of written documents. In this article, deed is intended to mean a written document drawn up for the specific purpose of proving a certain event and it is signed. There are two types of deed, namely authentic deed and privately drawn up deed. Under the provisions of law, privately drawn up deed is a deed which is not drawn up before a public officer, as set forth in Article 1874 of the Civil Code which reads as follows:

"Sebagai tulisan-tulisan di bawah tangan dianggap akta-akta yang ditandatangani di bawah tangan, surat-surat, register-register, surat-surat urusan rumah tangga dan lain-lain tulisan yang dibuat tanpa perantaraan seorang pegawai umum."

"Privately drawn up documents shall be considered to be privately signed deeds, letters, registers, documents pertaining to household matters and other documents, which are drawn up without the intervention of a public official." (Unofficial translation) 
These include documents such as the minutes of GMS drawn up without the attendance of a notary in the GMS concerned.

Regardless of the above, the purpose of drawing up of a deposit deed (akte van depot) by the notary is merely to enhance the authenticity of the document concerned and there are no specific provisions dealing with it in the UUPT. Accordingly, the document in the form of the minutes of the first, second and third GMS belong to the category of authentic deeds. Authentic deeds are provided for in Article 1868 of the Civil Code, which sets forth as follows:

"Suatu akta otentik ialah suatu akta yang di dalam bentuk yang ditentukan oleh undang-undang, dibuat di hadapan pegawai-pegawai umum yang berkuasa untuk itu di tempat di mana akta dibuatnya."

An authentic deed is a deed drawn up in a format prescribed by law, before public officials who are authorized to do so at the location where it is drawn up." (Unofficial translation) proof.

Authentic deeds have the legal effect of conclusive, binding and material

Even though there is a difference between authentic and privately drawn up deeds in terms of the degree of their effect as proof respectively, the provisions of Articles 1875, 1876 and 1877 of the Civil Code need to be taken into account specifically concerning the legal effect of privately drawn up deeds as evidence, setting forth as follows:

Article 1875 of the Civil Code:

"Suatu tulisan di bawah tangan yang diakui oleh orang terhadap siapa tulisan itu hendak dipakai, atau dengan cara yang menurut undang-undang dianggap sebagai bukti yang diakui, memberikan terhadap orang-orang yang menandatanganinya serta para ahli warisnya dan orang-orang yang mendapat hak daripada mereka, bukti yang sempurna seperti suatu akta otentik, dan demikian pula berlakulah ketentuan Pasal 1871 untuk tulisan tersebut."

"A private document, which has been acknowledged by the individual to whom it is addressed, or which is considered as legally recognized evidence, shall provide, with respect to the signatories thereto and their heirs and parties having rights therein, conclusive evidence similar to an authentic deed, and the stipulation in article 1871 shall also be applicable to such private document." (Unofficial translation)

Article 1876 of the Civil Code:

"Barang siapa terhadapnya dimajukan suatu tulisan di bawah tangan, diwajibkan secara tegas mengakui atau memungkiri tandatangannya; ..."

"An individual, whose privately drawn up document has been disputed, shall be required to expressly acknowledge or deny that such is his/her signature; ..." (Unofficial translation)

Article 1877 of the Civil Code:

"Jika seseorang memungkiri tulisan atau tandatangannya, ataupun jika 
ahli warisnya atau orang-orang yang mendapat hak daripadanya menerangkan tidak mengakuinya, maka hakim harus memerintahkan supaya kebenaran dari tulisan atau tandatangan tersebut diperiksa dimuka pengadilan."

"In the event that a person denies the writing or signature as his/her, or if the heirs or the rightful parties declare that they do not recognize the same, the judge shall order that the authenticity thereof be investigated before the court." (Unofficial translation)

This is different from the confirmation GMS where the resolution of the GMS resolution is adopted based on the Court's stipulation. For such resolution, a Deed on the Statement of the GMS Resolution and even a Deed of the Minutes of GMS are drawn up.

It is expected that through the above described steps, the handling judge will be able to understand the internal conditions faced by the management of the company concerned leading to the filing of the above mentioned request for the determination of the GMS, for the settlement of debts and liabilities by the company's board of directors.

Furthermore, in view of all of the foregoing concerning the process of filing for the stipulation of the quorum of attendance and decision making in the GMS, it is applicable not only under Article 86 of the UUPT, but presumably it can also be applied in respect of Articles 88 and 89 of the UUPT.

\section{Conclusion}

Based on the foregoing, the following conclusions can be made:

1. The provisions of Article 86 of the UUPT are not entirely effective, particularly in view of the provisions for the filing of a request for Court stipulation, whereby Article 86 of the UUPT fails to take full account of the following conditions:

a. The absence of one of the shareholders due to the element of deliberateness;

b. The address of a shareholder is unclear;

c. The time frame provided for under Article 86 paragraph (9) is no in line with the time frame for filing a request for Court stipulation up to the time at which a decision on such Court stipulation is issued;

d. The time frame for serving official and appropriate summons, whereby an opportunity is given to serve summons 3 (three) times, with 1 (one) week for each summons, thus requiring a total of 3 (three) weeks.

e. The possibility of serving official and appropriate summons (relaas) by delegation, outside its domestic jurisdiction, or even outside the state territory of the Republic of Indonesia.

2. The party filing a request must be able to convince the judge that the essence of the issue is limited to a situation whereby the non-achievement of attendance quorum has a direct impact on the company's performance.

3. The judge is required to be able to make a clear distinction concerning the substance of the case, namely whether the request for stipulation is a voluntary request or whether it actually contains the factors of a dispute. 
Guided by such understanding, the judge will be able to make a more incisive decision in determining whether to accept or to reject the request concerned.

4. There is also a need to understand that, in effect, the provisions of Article 86 of the UUPT also provide protection to other shareholders against deposition or unfair treatment, particularly in cases where neglectful absence is used as a basis for requesting a stipulation. The intent is to ensure that the quorum of the meeting cannot be changed easily.

\section{Bibliography}

\section{Books}

M. Yahya Harahap,(2011), Hukum Perseroan Terbatas (Limited Liability Company Law), third edition, PT. Sinar Grafika, Jakarta. (2005), Hukum Acara Perdata tentang Gugatan, Persidangan, Penyitaan, Pembuktian dan Putusan Pengadilan (Civil Procedural Law about Claim, Hearing, Seizure, Substantiation and Court Decision), second edition, PT. SinarGrafika, Jakarta.

Low CheeKeong, Introduction the Corporate Governance Debate, Corporate Governance an Asia Pacific Critique, Sweet \& Maxwell Asia a Thompson Company

\section{Websites}

http://prayitnobambang.blogspot.com/2011/11/bab-i-kontrak-joint-venture.html

http://legal-dictionary.thefreedictionary.com//oint+Venture 